\title{
Sagebrush response to ungulate browsing in Yellowstone
}

\author{
CARL L. WAMBOLT AND HARRIE W. SHERWOOD
}

Authors are professor and research associate, Department of Animal and Range Sciences, Montana State University, Bozeman, Mont. 59717.

\begin{abstract}
Big sagebrush (Artemisia tridentata Nutt.) declined from ungulate browsing during the first half of the twentieth century on the Northern Yellowstone Winter Range. It was our objective to compare shrub parameters of Northern Yellowstone Winter Range sagebrush habitat types continually browsed or protected for 32 to 37 years. Measurements were taken in and out of exclosures for 19 environmentally paired, protected, and browsed sites. We found significant differences in development between protected and browsed shrubs. Big sagebrush canopy cover at the 19 sites averaged $19.7 \%$ with protection and $6.5 \%$ where browsed $(P \leq 0.0027)$, and plants were twice as numerous $(P \leq \mathbf{0 . 0 0 2 7})$ under protection. Winter forage production of individual big sagebrush plants was also greater under protection at 16 of the 19 paired sites $(\mathbf{P} \leq 0.0027)$. Subdominant sprouting shrubs generally responded the same as big sagebrush. This ungulate induced decline of shrubs has implications for many Northern Yellowstone Winter Range values. Ultimately many organisms are sacrificed with the loss of quality big sagebrush habitat.
\end{abstract}

Key Words: Artemisia tridentata, big sagebrush, winter range, Cervus elaphus, elk, Odocoileus hemionus, mule deer, Antilocapra americana, pronghorn.

Since at least the 1920's, the effects of large populations of ungulates on the Northern Yellowstone Winter Range have been debated. Most attention has focused on the larger woody plants, primarily aspen (Populus tremuloides Michx.) and willows (Salix L.). Since adoption of the Natural Regulation Policy in 1968 in Yellowstone National Park there has been little concern for the decline of woody plants, especially sagebrush (Artemisia L.) taxa (Wambolt 1998). However, during the early twentieth century a good deal of concern was expressed for the welfare of sagebrush within Yellowstone National Park (Rush 1932, Wright and Thompson 1935, Cahalane 1943, Kittams 1950). In response, the National Park Service constructed 10 exclosures on the Northern Yellowstone Winter Range in 1957 and 1962, a period of high

We express our appreciation to Dr. William Quimby of the Department of Mathematical Sciences, Montana State University, for assistance in study design and conducting the statistical analyses and to Julie Fortney for assistance in data collection.

Manuscript accepted 23 Sept. 1998.

\section{Resumen}

En el "Northern Yellowstone Winter Range", el "Big sagebrush" (Artemisa tridentata Nutt) declinó durante la primera parte del siglo veinte debido al ramoneo por los ungulados. Nuestro objetivo fue comparar los parámentros de arbustos en tipos de hábitats de "sagebrush"en el "Northern Yellowstone Winter Range" y que han sido continuamente ramoneados o protegidos del ramoneo durante 32 a 37 años. Las mediciones fueron tomadas dentro y fuera de exclusiones en 19 sitios ambientalmente apareados con y sin ramoneo. Encontramos diferencias significativas en el desarrollo de arbustos ramoneados y protegidos. La cobertura de copa del "Big sagebrush" en los 19 sitios promedió $19.7 \%$ con protección y $6.5 \%$ cuando fueron ramoneadas $(\mathrm{P} \leq 0.0027)$ y el número de plantas fue el doble en las áreas protegidas ( $\mathrm{P} \leq$ 0.0027). En 16 de los 19 sitios, la producción de forraje en invierno de plantas individuales de "Big sagebrush" también fue mayor cuando los arbustos estuvieron protegidos $(\mathbf{P} \leq$ 0.0027). Los arbustos rebrotantes subdominates generalmente respondieron de la misma manera que el "Big sagebrush". Esta reducción de arbustos inducida por los ungulados tiene implicaciones para muchos de los valores del "Northern Yellowstone Winter Range". Finalmente muchos organismos son sacrificados con la pérdida de calidad del hábitat del "Big sagebrush"

elk numbers, partially to study the relationships between ungulate foraging and sagebrush. Eight of these exclosures still exist, of which 4 are totally in sagebrush habitat types and all 8 contain a significant portion within a sagebrush habitat type. Recently, more attention has been given sagebrush taxa on the Northern Yellowstone Winter Range regarding their forage relationships with ungulates. Investigations have determined mechanisms unique to sagebrush taxa and the Northern Yellowstone Winter Range that influence sagebrush browsing patterns and heavy levels of use (Personius et al. 1987, Striby et al. 1987, Wambolt and McNeal 1987, Bray et al. 1991, Wambolt et al. 1994, Singer and Renkin 1995, Wambolt 1996). To refine our knowledge of sagebrush-herbivory relationships on the Northern Yellowstone Winter Range, it was our objective to compare parameters between shrubs ungulate browsed or protected since exclosure construction. 


\section{Methods}

\section{Study Area}

The Northern Yellowstone Winter Range occupies 100,000 ha over an 80 $\mathrm{km}$ stretch along the lower elevations in northern Yellowstone National Park and extends northward into Montana along the Yellowstone River drainage (Houston 1982). The Lamar and Gardiner rivers also drain portions of the lowlands in Yellowstone National Park that are relatively free of snow, thereby providing a reliable winter location for ungulate foraging (Houston 1982). Singer (1991) reported that $80 \%$ of the ungulates in Yellowstone National Park during winter are found on the Northern Yellowstone Winter Range. In addition, up to 2,544 Rocky Mountain mule deer (Odocoileus hemionus hemionus) and 8,626 Rocky Mountain elk (Cervus elaphus nelsoni) have been counted during late winter on the portion of the Northern Yellowstone Winter Range north of the Yellowstone National Park boundary in Montana (Unpublished data, Montana Fish, Wildlife \& Parks). Actual counts (no adjustment for sightability) of elk on the Northern Yellowstone Winter Range increased from an average of 4,382 animals during the 1962 to 1969 period (Houston 1982) (pre-Natural Regulation influence) to an average of 17,409 based on 9 counts between 1982 and 1995, after adoption of the Natural Regulation Policy (Unpublished data, Montana Fish, Wildlife \& Parks).

The favorable climate for ungulate winter foraging varies across the Northern Yellowstone Winter Range. Coughenour (1991) reported $279 \mathrm{~mm}$ of annual precipitation at Gardiner, Montana $(1,616 \mathrm{~m}), 398 \mathrm{~mm}$ at Mammoth $(1,899 \mathrm{~m})$, and $406 \mathrm{~mm}$ at Tower Falls $(1,912 \mathrm{~m})$. Within the portion of the Northern Yellowstone Winter Range used in this study, Gardiner is the lowest elevation studied, while some sites were 100-200 $\mathrm{m}$ higher than Tower Falls. Half of the precipitation is received as snow although peak moisture is received in spring and early summer (Farnes 1991). The soils at the study sites are typic calciborolls, aridic haploborolls, and aridic calciborolls (Lane 1990). The Gardiner area is located on ancient mudflows which are higher in clay and lower in fertility than the rest of the study area.
The habitat type in the Gardiner area is Wyoming big sagebrush (Artemisia tridentata ssp. wyomingensis Beetle and Young)bluebunch wheatgrass (Agropyron spicatum [Rydb.] Scribn.). Over the rest of the Northern Yellowstone Winter Range the mountain big sagebrush (A. $t$. ssp. vaseyana [Rydb.] Beetle)-Idaho fescue (Festuca idahoensis Elmer)-bluebunch wheatgrass habitat type dominates. Important plants include the sprouting shrubs associated with sagebrush habitat types, specifically rubber rabbitbrush (Chrysothamnus nauseosus [Pall.] Britt.), green rabbitbrush (C. viscidiflorus [Hook.] Nutt.) and gray horsebrush (Tetradymia canescens D.C.) which were found throughout the study area. Other important grasses were prairie junegrass (Koeleria macrantha Ledeb.), and Sandberg bluegrass (Poa secunda Presl.).

Pronghorn (Antilocapra americana americana), mule deer, and elk occupy the portion of the Northern Yellowstone Winter Range studied near Gardiner. Only elk forage on sagebrush in significant numbers during winter over the rest of the Northern Yellowstone Winter Range (Singer and Renkin 1995). During the last decade bison (Bison bison bison) have been observed near some of the exclosures, but there is no evidence that bison have had significant impact on the shrubs of sagebrush habitat types.

\section{Sampling and Analysis}

Sampling followed the general procedure detailed by Coughenour (1991). Because the large Yellowstone fires of 1988 burned the vegetation in 2 of the 8 remaining exclosures, measurements were taken in (protected) and near (browsed) the 6 unburned exclosures (Table 1). The 2 ha exclosures contained considerable environmental variation. Because important differences in shrub parameters could exist among various environmental conditions, the sagebrush habitat type within each exclosure was stratified to separate topographic, soil, and microclimatic variation (Coughenour 1991). Pairing sites with similar slopes and aspects accomplished this stratification. This resulted in 19 environmentally paired sites within and adjacent to the 6 exclosures. Coughenour (1991) emphasized that this stratification procedure is preferable to pure randomization in experiments of this nature to insure that
Table 1. Slopes and aspects at the 19 locations where browsed and protected sites were paired by both characters. The paired sites are associated with the 6 exclosures established either in 1957 or 1962 (Lamar-57 etc.) that were not burned during the Yellowstone fires of 1988.

\begin{tabular}{lcc}
\hline \hline Site $^{1}$ & \multicolumn{1}{c}{ Slope $^{2}$} & Aspect \\
\hline Mammoth-57 & Gentle & NWW \\
Junction Butte-62A & Moderate & SE \\
Junction Butte-62B & Gentle & N \\
Lamar-57A & Steep & SSW \\
Lamar-57B & Very steep & SW \\
Lamar-57C & Moderate & SW \\
Lamar-57D & Steep & SW \\
Lamar-62A & Steep & S \\
Lamar-62B & Very steep & S \\
Lamar-62C & Moderate & S \\
Lamar-62D & Moderate & SW \\
Gardiner-57A & Flat & Flat \\
Gardiner-57B & Steep & E \\
Gardiner-57C & Gentle & SW \\
Gardiner-57D & Gentle & NWW \\
Gardiner-62A & Moderate & NEE \\
Gardiner-62B & Flat & Flat \\
Gardiner-62C & Very steep & NEE \\
Gardiner-62D & Very steep & SE \\
\hline The 8 Gardin & artes &
\end{tabular}

The 8 Gardiner sites are dominated by Wyoming big sagebrush and the other 11 sites by mountain big sagebrush

Slope classes are: Flat $\leq 3 \%$, Gentle $=4-15 \%$, Moderate $=16-29 \%$, Steep $=30-44 \%$, Very steep $\geq 45 \%$.

${ }^{3}$ At these locations a remote site was paired environmentally with the original protected and browsed pair.

biases are not allowed by inadvertent grouping of samples on a confounding environmental gradient (Hurlbert 1984). We agree with Coughenour (1991) that with random sampling using paired sites (in and out of the exclosures) it is unlikely that comparable distributions of topo-edaphic positions would have been obtained, regardless of sample size.

No sampling outside exclosures was done within $50 \mathrm{~m}$ of the fenceline to avoid a potential "exclosure effect" created by ungulates walking the perimeter fence. To further assure that we were not measuring an "exclosure effect", we also environmentally paired remote sites with 4 of the 19 original paired sites. The 4 remote browsed sites were located between $300 \mathrm{~m}$ and $450 \mathrm{~m}$ from the exclosures.

Data were collected during summer 1994. Canopy coverage and density of big sagebrush and sprouting shrubs were compared in and out of the exclosures. In addition, winter forage production was estimated for big sagebrush subspecies (Wambolt et al. 1994). At each of the 19 sites, ten, 30-m transects were located inside the exclosure and another 
10 transects outside the exclosure by stratifying the site so that each transect would represent an equal sized portion of the entire site. Along each 30-m transect, the line interception method (Canfield 1941) was used to obtain percent shrub canopy coverage. All shrub canopy segments of at least $3 \mathrm{~cm}$ were included. Along each 30-m line, belt transects of $2 \times 30 \mathrm{~m}$ were created by measuring $1 \mathrm{~m}$ on both sides of the line transect. Densities of established shrubs were obtained within the 10 belt transects. Established shrubs were considered to be those having an average horizontal axis (canopy) $\geq 15 \mathrm{~cm}$ from 4 canopy measurements (Wambolt et al. 1994). All measurements were taken in a similar manner at the 4 remote locations.

Winter forage production of big sagebrush was estimated by using models developed on the Northern Yellowstone Winter Range for individual subspecies and browse form classes (Wambolt et al. 1994). These models will predict winter forage production $\left(\mathrm{R}^{2}=0.91-0.94\right)$ for plants with $\geq 15 \mathrm{~cm}$ average canopy. Specific measurements varied depending on taxon and browse form class (Wambolt et al. 1994). Ten plants for production measurements were selected in each belt transect by totaling the number of plants and dividing by 10 , after which every plant of that multiple was measured. On the browsed portion of the 8 Gardiner paired sites, winter forage production of Wyoming big sagebrush could not be estimated because plants $>15 \mathrm{~cm}$ average canopy were not located.

Exploratory data analysis indicated unequal variances from site to site. Consequently, 2-sample $\mathrm{t}$ procedures were used at each site and over all sites to test for differences in canopy coverage, density, and winter forage production between protected and browsed shrubs. To make simultaneous inferences at the $\mathrm{P}=0.05$ level, the tests were adjusted using the Bonferroni (Neter et al. 1996) procedure. This adjustment yielded an overall comparative P-value of 0.0027 .

\section{Results and Discussion}

Since the period of exclosure construction in 1957 and 1962, there has been a significant difference in the development of protected and browsed big sagebrush communities (Fig. 1). Average big sagebrush canopy cover on protected sites (Table 2) was $202 \%$ greater $(\mathrm{P} \leq 0.0027)$ than on browsed sites over the 19 paired sites. The average big sagebrush cover for all 19 sites was $19.7 \%$ inside and $6.5 \%$ outside the exclosures. This relationship was universal on sites with Wyoming big sagebrush or mountain big sagebrush, flat to very steep topographies, and all aspects and precipitation levels.

The 8 study sites with Wyoming big sagebrush are in a locality that historically has been more heavily browsed than the portions of the Northern Yellowstone Winter Range with mountain big sagebrush (Houston 1982, Singer and Renkin 1995). This is logical as Wyoming big sagebrush favors the relatively dry environments that also offer the best winter foraging opportunities for ungulates. Partially due to both a lesser site potential and the long-term heavy browsing at the Wyoming big sagebrush sites, even with protection those 8 sites only averaged $7.8 \%$ cover compared to $28.4 \%$ for mountain big sagebrush at the 11 sites where it grows. The Wyoming big sagebrush sites under protection averaged $857 \%$ more sagebrush cover than where browsing has continued since 1957 and 1962. The same figure was also high for mountain big sagebrush at $166 \%$.

We found that although all of the 19 sites did not have the same potential to support big sagebrush, the relationships were consistent throughout the range of conditions represented. Big sagebrush cover in the protected portions of the study sites ranged from 1.4 to $49.5 \%$ and in the browsed portions from 0 to $28.7 \%$. The high cover $(49.5 \%)$ at the Mammoth-57 site indicates a favorable environment for sagebrush. Historically, the site probably has endured less browsing than the other sites due to its NWW aspect and gentle slope that both reduce solar radiation effectiveness coupled with relatively high amounts of snow at Mammoth. This conclusion is logical when Mammoth-57 is compared to Lamar-57-C and Lamar-62-C and D sites that also had high amounts of sagebrush cover with protection inside the exclosure. These 3 sites collectively had $30 \%$ as much sagebrush cover on the outside as on the inside, while the same figure for Mammoth-57 was 58\%. This was due at least partially to easier access for browsing ungulates with lesser snow accumulations on the Lamar sites resulting from steeper slopes on $\mathrm{S}$ to $\mathrm{SW}$ aspects. This combination greatly increases the effectiveness of solar radiation for melting snow (Trewartha 1968), thereby facilitating browsing.

Ungulate browsing also affected big sagebrush density. Big sagebrush plants 
Table 2. Percent canopy cover of big sagebrush at 19 environmentally paired sites either browsed or protected.

\begin{tabular}{lccc}
\hline \hline Site & Protected & Browsed & Probability $>\mathrm{t}^{1}$ \\
\hline & $-1-5)$ & $28.7(28.8)^{2}$ & 0.0004 \\
Mammoth-57 & 49.5 & $11.6(18.8)$ & 0.0000 \\
Junction Butte-62A & 31.9 & 11.5 & 0.0001 \\
Junction Butte-62B & 32.1 & 0.1 & 0.0291 \\
Lamar-57A & 3.2 & 0.1 & 0.0002 \\
Lamar-57B & 2.9 & 19.8 & 0.0004 \\
Lama-57C & 44.3 & 16.9 & 0.0015 \\
Lamar-57D & 25.4 & 1.3 & 0.0005 \\
Lamar-62A & 9.3 & 8.2 & 0.0001 \\
Lamar-62B & 29.6 & $9.3(9.0)$ & 0.0004 \\
Lamar-62C & 41.7 & 0.7 & 0.0000 \\
Lamar-62D & 42.1 & 0.1 & 0.0001 \\
Gardiner-57A & 3.9 & 1.1 & 0.0004 \\
Gardiner-57B & 3.6 & 0.4 & 0.0001 \\
Gardiner-57C & 4.5 & 0.4 & 0.0073 \\
Gardiner-57D & 1.4 & $4.3(1.5)$ & 0.0001 \\
Gardiner-62A & 21.8 & 0.2 & 0.0000 \\
Gardiner-62B & 17.6 & 0.0 & 0.0012 \\
Gardiner-62C & 2.4 & & 0.0001 \\
Gardiner-62D & 6.8 & & \\
The comparative P value for similar inferences is 0.0027. & \\
2Numbers in parentheses in this column are the percent canopy cover of big sagebrush at a remote site that paired envi- \\
ronmentally with the protected and browsed pair.
\end{tabular}

across the Northern Yellowstone Winter Range were twice as numerous with protection as with browsing (Table 3 ). The average density of big sagebrush plants was 30.5 per $60 \mathrm{~m}^{2}$ inside and 15.3 per $60 \mathrm{~m}^{2}$ outside the exclosures ( $\mathrm{P}$ $\leq 0.0027$ ). Big sagebrush cover and density were highly associated $(\mathrm{r}=0.92 ; \mathrm{P}$ $\leq 0.000$ ) inside the exclosures with protection and also outside where browsing occurred $(\mathrm{r}=0.93 ; \mathrm{P} \leq 0.000)$. Although the correlations are strong, there were some situations where a relatively large number of small sagebrush plants were found. These aggregations were in openings in the sagebrush canopy created where the predecessor plants had been overbrowsed, allowing seedlings to establish. Although snow cover is relatively light throughout the Northern Yellowstone Winter Range, some snow falls each winter and may protect the small plants for several years before they are available for ungulate foraging. Hoffman (1996) working in the Gardiner basin of the Northern Yellowstone Winter Range found that $47 \%$ of all the mountain big sagebrush plants that established during the 1978-1992 period, established during 1988. That year offered relatively good seed production due to plentiful spring moisture followed by a winter with considerably more snow than prevailed through the 15 year period (Hoffman 1996). These conditions were coupled with a great reduction in elk (Montana Fish, Wildlife \& Parks and Yellowstone National Park unpublished data) due to the most severe winter of the period in 1988-1989, and some loss of forage from the large 1988 Yellowstone fires.

Individual mountain big sagebrush plants produced $88 \%$ more winter forage where protected $(\mathrm{P} \leq 0.0027)$ (Table 4). Only the 11 sites with mountain big sagebrush were included in Table 4 , as browsed portions of all 8 Wyoming big
${ }^{T}$ The comparative $\mathrm{P}$ value for similar inferences is 0.0027 . sagebrush sites contained only sagebrush plants that were too small $(\leq 15 \mathrm{~cm}$ average canopy) for production to be estimated by the model (Wambolt et al. 1994). Therefore, of the 19 protected sites, all 8 Wyoming big sagebrush sites plus 8 of the 11 mountain big sagebrush sites produced significantly $(\mathrm{P} \leq 0.0027)$ more winter forage on a per-plant basis than the browsed portions of the site. Big sagebrush winter forage production can be converted to a unit area basis when used with density. Because the density of protected plants was also significantly greater $(\mathrm{P} \leq 0.0027)$ than for browsed plants at 15 sites, considerably more big sagebrush winter forage was produced per unit area on protected sites.

Sprouting shrubs (rubber rabbitbrush, green rabbitbrush, and gray horsebrush), comprised much less canopy cover than did big sagebrush (Table 5). The sprouting shrubs collectively averaged $2 \%$ cover in the protected areas and $1.1 \%$ in the paired browsed locations ( $\mathrm{P} \leq$ $0.0027)$. The relationship of more sprouting shrub cover on the protected sites was not consistent at all locations. However, 12 of the 19 sites did have more sprouting shrub cover measured on the protected portion of the site, but the difference in this character was only significant at 3 locations.

Density of sprouting shrubs averaged 16.6 per $60 \mathrm{~m}^{2}$ where protected, compared to 13.1 per $60 \mathrm{~m}^{2}$ on the browsed

Table 3. Number of big sagebrush plants (with a minimum canopy of $15 \mathrm{~cm}$ ) per $60 \mathrm{~m}^{2}$ at 19 environmentally paired sites either browsed or protected.

\begin{tabular}{lccc}
\hline \hline Site & Protected & Browsed & Probability $>\mathrm{t}^{1}$ \\
\hline & $-\cdots-\cdots$ & \\
Mammoth-57 & 51.6 & $51.5(53.6)^{2}$ & 0.9843 \\
Junction Butte-62A & 51.3 & $24.3(24.9)$ & 0.0001 \\
Junction Butte-62B & 54.9 & 33.4 & 0.0000 \\
Lamar-57A & 2.3 & 0.4 & 0.0022 \\
Lamar-57B & 7.9 & 0.0 & 0.0001 \\
Lamar-57C & 56.7 & 37.2 & 0.0000 \\
Lamar-57D & 46.0 & 42.9 & 0.4202 \\
Lamar-62A & 34.0 & 7.0 & 0.0006 \\
Lamar-62B & 53.0 & 37.3 & 0.0018 \\
Lamar-62C & 52.4 & $18.4(18.3)$ & 0.0000 \\
Lamar-62D & 45.6 & 29.7 & 0.0046 \\
Gardiner-57A & 9.0 & 0.5 & 0.0002 \\
Gardiner-57B & 8.1 & 0.5 & 0.0002 \\
Gardiner-57C & 15.1 & 5.0 & 0.0005 \\
Gardiner-57D & 7.7 & 1.0 & 0.0001 \\
Gardiner-62A & 36.0 & 1.2 & 0.0001 \\
Gardiner-62B & 39.2 & $0.2(1.6)$ & 0.0001 \\
Gardiner-62C & 2.2 & 0.0 & 0.0090 \\
Gardiner-62D & 6.9 & 0.7 & 0.0001 \\
\hline
\end{tabular}

${ }^{2}$ Numbers in parentheses in this column are the number of big sagebrush plants at a remote site that paired environmentally with the protected and browsed pair. 
portions of the 19 sites. For 4 of the 19 paired locations the differences between their values were statistically significant, 3 of which had more individuals on the protected portion (Table 6).

In general, response of the sprouting shrubs was similar to that of big sagebrush over the Northern Yellowstone Winter Range. Not surprisingly, the degree of response to browsing and protection was considerably less for the sprouting shrubs than for the nonsprouting big sagebrush. Sprouters often initially thrive with disturbance like heavy browsing as they sustain prolonged herbivory better than nonsprouters. The taxa we measured are known to often benefit when associated species are preferred forages and overutilized (Young and Evans 1978, Blaisdell et al. 1982). On the Northern Yellowstone Winter Range the dominant big sagebrush has been reduced from intense browsing, thereby providing the subdominant sprouting shrubs an opportunity to increase. Although no production data were obtained for our sprouting shrubs, it is obvious that the biomass produced by these plants is small on the Northern Yellowstone Winter Range, despite the inherent resiliency of sprouting shrubs to browsing. Apparently even the sprouting shrubs have been retarded by Northern Yellowstone Winter Range browsing over the long-term $(\mathrm{P} \leq 0.0027)$.

The 4 remote sites that we matched with specific paired sites assured us that we were not biasing our results by measuring an "exclosure effect" created when ungulates might forage heavily along exclosure perimeters. All of the tvalues found comparing the 4 remote locations and the paired 4 protected sites arrived at the same conclusions for the 5 parameters in Tables 2-6.

Pronghorn and mule deer often forage heavily on big sagebrush taxa (Welch and McArthur 1979). Mule deer diets averaged $52 \%$ big sagebrush over a 10 year period (Wambolt 1996) only a couple $\mathrm{km}$ away from the 8 Wyoming big sagebrush sites. A high degree of utilization is reflected in the great impact on Wyoming big sagebrush populations at these 8 sites where elk may also be present with pronghorn and mule deer (Singer and Renkin 1995). However, as Singer and Renkin (1995) point out, elk are the only significant browsers at the other 11 sites due to excessive snow

Table 4. Average grams of winter forage produced per mountain big sagebrush plant at 11 environmentally paired sites either browsed or protected. The 8 Gardiner area Wyoming big sagebrush sites are not included because browsed plants at those sites were too severely impacted by browsing to meet the minimum size requirements to model production. This obviously resulted in significantly less production where browsed at each of those 8 sites.

\begin{tabular}{lccc}
\hline \hline Site & Protected & Browsed & Probability $>\mathrm{t}^{1}$ \\
\hline & $-\ldots-\ldots-\ldots(\mathrm{g})$ & $-\ldots-\ldots \ldots$ & \\
Mammoth-57 & 184.5 & $99.9(113.5)^{2}$ & 0.0000 \\
Junction Butte-62A & 161.3 & $88.0(90.3)$ & 0.0000 \\
Junction Butte-62B & 200.1 & 92.1 & 0.0001 \\
Lamar-57A & 86.0 & 21.5 & 0.0039 \\
Lamar-57B & 93.7 & 0.0 & 0.0001 \\
Lamar-57C & 222.5 & 133.1 & 0.0003 \\
Lamar-57D & 120.8 & 108.7 & 0.2069 \\
Lamar-62A & 96.2 & 70.2 & 0.0001 \\
Lamar-62B & 141.0 & 83.3 & 0.0126 \\
Lamar-62C & 122.5 & $80.6(99.7)$ & 0.0023 \\
Lamar-62D & 188.0 & 81.3 & 0.0000
\end{tabular}

The comparative $\mathrm{P}$ value for similar inferences is 0.0027 .

${ }^{2}$ Numbers in parentheses in this column are winter forage produced per big sagebrush plant at a remote site that paired environmentally with the protected and browsed pair.

depths. Therefore, with our findings, it becomes obvious that elk numbers were large enough on the Northern Yellowstone Winter Range for a sufficient number of years before exclosure construction started in 1957 to greatly reduce big sagebrush populations (Rush 1932, Wright and Thompson 1935, Cahalane 1943, Kittams 1950).

Mountain big sagebrush on the Northern Yellowstone Winter Range was preferred over Wyoming big sagebrush by mule deer and elk (Wambolt 1996). The fact Wyoming big sagebrush in this study is impacted from browsing even more than mountain big sagebrush is therefore, a function of snow depth

Table 5. Percent canopy cover of all sprouting shrubs at 19 environmentally paired sites either browsed or protected.

\begin{tabular}{lcll}
\hline \hline Site & Protected & Browsed & Probability $>\mathrm{t}^{1}$ \\
\hline & $-1 .-1 \%)$ & \\
Mammoth-57 & 1.9 & $2.5(2.4)^{2}$ & 0.5452 \\
Junction Butte-62A & 0.3 & $0.5(1.2)$ & 0.3336 \\
Junction Butte-62B & 6.7 & 3.9 & 0.0464 \\
Lamar-57A & 4.6 & 2.1 & 0.0128 \\
Lamar-57B & 2.7 & 3.0 & 0.6975 \\
Lamar-57C & 0.1 & 0.3 & 0.2660 \\
Lamar-57D & 1.6 & 0.6 & 0.1172 \\
Lamar-62A & 6.1 & 0.8 & 0.0106 \\
Lamar-62B & 1.5 & 3.2 & 0.0028 \\
Lamar-62C & 0.3 & $0.3(0.5)$ & 0.9196 \\
Lamar-62D & 0.0 & 0.0 & 0.0089 \\
Gardiner-57A & 1.9 & 0.6 & 0.0367 \\
Gardiner-57B & 2.3 & 1.3 & 0.0226 \\
Gardiner-57C & 2.0 & 1.1 & 0.0007 \\
Gardiner-57D & 2.7 & 0.9 & 0.0002 \\
Gardiner-62A & 1.0 & 0.2 & 0.0223 \\
Gardiner-62B & 0.1 & $0.0(0.4)$ & 0.0000 \\
Gardiner-62C & 1.9 & 0.3 & 0.0146 \\
Gardiner-62D & 0.8 & 0.1 &
\end{tabular}

The comparative $\mathrm{P}$ value for similar inferences is 0.0027 .

${ }^{2}$ Numbers in parentheses in this column are percent canopy cover of sprouting shrubs at a remote site that paired environmentally with the protected and browsed site. limiting pronghorn and mule deer foraging instead of a foraging preference for Wyoming big sagebrush. The crude terpenoids present in 4 sagebrush taxa on the Northern Yellowstone Winter Range explained why ungulates displayed a preference (Personius et al. 1987, Bray et al. 1991). However, a 10 year data set made it clear that any of the sagebrush taxa on the Northern Yellowstone Winter Range would be heavily browsed if winter conditions precluded ungulates from exercising their preferences (Wambolt 1996).

Other studies conducted at Northern Yellowstone Winter Range exclosures have concluded that ungulate foraging 
Table 6. Number of sprouting shrubs per $60 \mathrm{~m} 2$ at 19 environmentally paired sites either browsed or protected.

\begin{tabular}{|c|c|c|c|}
\hline Site & Protected & Browsed & Probability $>\mathrm{t}^{1}$ \\
\hline & $-\cdots-\cdots$ (No.) & -------- & \\
\hline Mammoth-57 & 29.0 & $33.4(34.8)^{2}$ & 0.5404 \\
\hline Junction Butte-62A & 5.1 & $12.6(18.3)$ & 0.0054 \\
\hline Junction Butte-62B & 60.3 & 81.6 & 0.0021 \\
\hline Lamar-57A & 34.4 & 18.0 & 0.0126 \\
\hline Lamar-57B & 22.0 & 7.8 & 0.0000 \\
\hline Lamar-57C & 5.3 & 6.5 & 0.4155 \\
\hline Lamar-57D & 18.6 & 8.5 & 0.0546 \\
\hline Lamar-62A & 47.4 & 5.9 & 0.0001 \\
\hline Lamar-62B & 19.7 & 30.3 & 0.0063 \\
\hline Lamar-62C & 9.5 & $5.0(7.4)$ & 0.0484 \\
\hline Lamar-62D & 8.3 & 8.2 & 0.9980 \\
\hline Gardiner-57A & 8.8 & 6.6 & 0.2169 \\
\hline Gardiner-57B & 10.9 & 6.5 & 0.0660 \\
\hline Gardiner-57C & 7.4 & 5.7 & 0.3810 \\
\hline Gardiner-57D & 3.1 & 7.6 & 0.0117 \\
\hline Gardiner-62A & 22.3 & 3.3 & 0.0019 \\
\hline Gardiner-62B & 0.1 & $0.0(4.8)$ & 0.3434 \\
\hline Gardiner-62C & 1.8 & 1.7 & 0.8944 \\
\hline Gardiner-62D & 1.0 & 0.4 & 0.2011 \\
\hline
\end{tabular}

The comparative $\mathrm{P}$ value for similar inferences is 0.0027

${ }^{2}$ Numbers in parentheses in this column are the number of sprouting shrubs at a remote site that paired environmentally with the protected and browsed pair.

has had little effect on the vegetation (Coughenour 1991, Singer and Renkin 1995). Singer and Renkin (1995) reported that ungulates had suppressed Wyoming big sagebrush on the lower elevations of the Northern Yellowstone Winter Range, but had not affected the preferred mountain big sagebrush (Wambolt 1996), the dominant on $97 \%$ of the Northern Yellowstone Winter Range sagebrush habitat types. Singer and Renkin (1995) relied on data obtained from single paired belt transects $(1.5 \mathrm{~m} \times 30.5 \mathrm{~m})$ established when the exclosures were constructed. These transects sampled $<8 \%$ of the area included in our belt transects for the first 5 years of their data. Singer and Renkin (1995) obtained additional information in 1986 and 1987 by sampling a total of $140 \mathrm{~m}^{2}$ (23\% of our sampled area) in 15 randomly located $9.3 \mathrm{~m}^{2}$ circular plots both inside and outside 6 exclosures. We conclude that our results differ from Singer and Renkin (1995) due to their smaller sample in combination with their random placement of the plots. We agree with Coughenour (1991), as discussed earlier, that randomization is not desirable in such situations.

Coughenour (1991) studied responses of herbaceous vegetation at 4 of the Northern Yellowstone Winter Range exclosures. His conclusions were that elk winter grazing generally did not reduce productivity of herbaceous plants and that because root biomass of herbs was not affected by grazing that there was no net consequence of winter grazing on the herbs. Because we studied browse, our results are not contradictory. However, if no differences between inside and outside these exclosures are found, it is possible that the approximately 50 years of intense herbivory prior to exclosure construction produced a long-term effect that persists to the present inside the exclosure. Thus, finding no difference does not necessarily mean that recent herbivory has no impact. However, if studies like ours document differences at these sites, it can be assumed that the changes are due to protection from herbivory. It is clear that we did not simply measure shrub decline outside the exclosures compared to a climatically determined historical level inside each exclosure. We measured changes in big sagebrush parameters since exclosure construction in 1957 and 1962. We do not have assurance that the recovery inside exclosures is complete.

Singer and Renkin (1995) concluded that the $66 \%$ decline in mule deer using the lower elevation within the Northern Yellowstone Winter Range over the previous 2 decades may be due to the decline in Wyoming big sagebrush. We concur and believe the decline we found across the Northern Yellowstone Winter Range in both Wyoming and mountain big sagebrushes negatively impacts each of the ungulates that forage on these taxa. The value of big sagebrush as a highly digestible and nutritious forage is well established (Welch and McArthur 1979). Other Northern Yellowstone Winter Range values would be similarly affected with the demise of the natural dominant vegetation (Wambolt 1998). This decline of habitat value in the extensive big sagebrush habitat types of the Northern Yellowstone Winter Range will extend well beyond ungulates to reduce many native organisms (Welch 1997). To arrest this trend, ungulate numbers, especially elk, would have to be reduced. At present such action would conflict with the Yellowstone National Park policy of Natural Regulation.

\section{Literature Cited}

Blaisdell, J.P., R.B. Murray, and E.D. McArthur. 1982. Managing intermountain rangelands: Sagebrush-grass ranges. USDA Forest Serv. Gen. Tech. Rep. INT134.

Bray, R.O., C.L. Wambolt, and R.G. Kelsey. 1991. Influence of sagebrush terpenoids on mule deer preference. J. Chem. Ecol. 17:2053-2062.

Cahalane, V.H. 1943. Elk management and herd regulation-Yellowstone National Park. Transactions of the North American Wildlife Conference. 8:95-101.

Canfield, R. 1941. Application of the line interception method in sampling range vegetation. J. Forestry. 39:388-394.

Coughenour. M.B. 1991. Biomass and nitrogen responses to grazing of upland steepe on Yellowstone's northern winter range. J. Appl. Ecol. 28:71-82.

Farnes, P.E. 1991. A scaled index of winter severity. p. 135-138. Western Snow Conference, 12-15 April 1991; Juneau, Alaska. Colorado State Univ. Press, Fort Collins, Colo.

Hoffman, T.L. 1996. An ecological investigation of mountain big sagebrush in the Gardiner basin. M.S. Thesis, Montana State Univ. Bozeman, Mont.

Houston, D.B. 1982. The northern Yellowstone elk. Macmillan Pub. New York, N.Y.

Hurlbert, S.H. 1984. Pseudoreplication and the design of ecological field experiments. Ecol. Monographs. 54: 187-211.

Kittams, W.H. 1950. Sagebrush on the lower Yellowstone range as an indicator of wildlife stocking. Yellowstone National Park files. Mammoth, Wyo. 14 p. 
Lane, J. 1990. Characterization and comparison of soils inside and outside of grazing exclosures on Yellowstone National Park's northern winter range. M.S. Thesis, Montana State Univ. Bozeman, Mont.

Neter, J., M.H. Kutner, C.J. Nachtsheim, and W. Wasserman, 1996. Applied Linear Statistical Models. Irwin Publishing. 4th Edition.

Personius, T.L., C.L. Wambolt, J.R. Stephens, and R.G. Kelsey, 1987. Crude terpenoid influence on mule deer preference for sagebrush. J. Range Manage. 40:84-88.

Rush, W.M. 1932. Northern Yellowstone Elk Study. Montana Fish and Game Commission.

Singer, F.J. 1991. The ungulate prey base for wolves in Yellowstone National Park. p. 323-348 In: R.B. Keiter and M.S. Boyce, editors. The Greater Yellowstone Ecosystem: redefining America's wilderness heritage. Yale Univ. Press. New Haven, Conn.
Singer, F.J. and R.A. Renkin. 1995. Effects of browsing by native ungulates on the shrubs in big sagebrush communities in Yellowstone National Park. Great Basin Natur. 55:201-212.

Striby, K.D., C.L. Wambolt, R.G. Kelsey, and K.M. Havstad. 1987. Crude terpenoid influence on in vitro digestibility of sagebrush. J. Range Manage. 40:244-248.

Trewartha, G.T. 1968. An introduction to climate. McGraw-Hill. New York, N.Y.

Wambolt, C.L. 1996. Mule deer and elk foraging preference for 4 sagebrush taxa. J. Range Manage. 49:499-503.

Wambolt, C.L. 1998. Sagebrush and ungulate relationships on Yellowstone's northern range. Wildlife Soc. Bull. 26:429-437.

Wambolt, C.L. and A.F. McNeal. 1987. Selection of winter foraging sites by elk and mule deer. J. Environ. Manage. 25:285-291.

Wambolt, C.L., W.H. Creamer, and R.J. Rossi. 1994. Predicting big sagebrush winter forage by subspecies and browse form class. J. Range Manage. 47:231-234.
Welch, B.L. 1997. Seeded versus containerized big sagebrush plants for seed-increase gardens. J. Range Manage. 50:611-614.

Welch, B.L. and E.D. McArthur. 1979. Feasibility of improving big sagebrush (Artemisia tridentata) for use on mule deer winter ranges. p. 451-457. In: J.R. Goodin, and D.K. Northington (eds.), Arid land plant resources. Texas Tech Univ., Lubbock, Tex.

Wright, G.M. and B.H. Thompson. 1935. Fauna of the National Parks of the United States: wildlife management in the national parks. Fauna Series No. 2. U.S. Govt. Printing Office. Wash., D.C.

Young, J.A. and R.A. Evans. 1978. Population dynamics after wildfires in sagebrush grasslands. J. Range Manage. $31: 283-289$. 